\title{
Ерготерапія як складова частина реабілітаційного процесу при невропатіях верхніх кінцівок
}

\author{
УдК: 616.833-001.35.615.825 \\ O. В. Бісмак
}

Національний університет фізичного виховання і спорту України, Київ, Україна

\begin{abstract}
Анотація. Захворювання і травми периферичної нервової системи на сьогодні $€$ соціально значущою проблемою. Пошкодження рук є найбільш поширеними травмами, отриманими переважно особами працездатного віку. Для повернення пацієнта в повсякденне життя, суспільство та до професійної діяльності в реабілітаційний процес необхідно включати засоби ерготерапії. Мета. Розкрити значення ерготерапії в реабілітації осіб з невропатіями верхніх кінцівок. Методи. Аналіз, синтез та узагальнення даних науково-методичної літератури. Результати. У роботі узагальнено знання про роль ерготерапії при травматичних та компресійно-ішемічних невропатіях верхньої кінцівки. Зазначено цілі (короткострокові та довгострокові) та принципи ерготерапії при даній патології. Охарактеризовано основні стратегії відновлення можливостей хворих з невропатією верхньої кінцівки (розвиваюча та компенсаторна). Висновки. Ерготерапія $є$ важливою складовою реабілітаційного процесу в осіб з травматичними та компресійно-ішемічними невропатіями верхніх кінцівок, яка направлена на підвищення якості життя пацієнтів та відновлення або покращення їх активності та участі в усіх сферах життя. Проте літературні дані свідчать, що в нашій країні ще недостатньо уваги приділяють використанню ерготерапії при пошкодженнях периферичних нервів верхньої кінцівки і лише в поодиноких випадках застосовують на практиці.
\end{abstract}

Ключові слова: ерготерапія, невропатія, верхня кінцівка, ерготерапевтичні втручання.

Occupational therapy as a component of the rehabilitation process in neuropathies of the upper extremities

o. V. Bismak

National University of Physical Education and Sport of Ukraine

Abstract. Diseases and injuries of the peripheral nervous system are currently a socially significant problem. Hand injuries are the most common injuries sustained by people of predominantly working age. To return the patient to everyday life, society and professional activities, it is necessary to include methods of occupational therapy in the rehabilitation process. Objective. To reveal the importance of occupational therapy in the rehabilitation of patients with the upper extremity neuropathies. Methods. Analysis, synthesis and generalization of the data of scientific and methodological literature. Results. The paper summarizes the knowledge about the role of occupational therapy for traumatic and compressionischemic neuropathy of the upper extremity. The goals (short-term and long-term) and the principles of occupational therapy for this pathology are indicated. The main strategies for recovering the capabilities of a patient with neuropathy of the upper limb (developing and compensatory) are described. Conclusions. Occupational therapy is an important component of the rehabilitation of patients with traumatic and compression-ischemic neuropathy of the upper limb, aimed at improving the quality of life of patients and restoring or improving the activity and participation of patients in all areas of human life. However, literature data indicate that in our country, insufficient attention is paid to the use of occupational therapy for injuries of the peripheral nerves of the upper limb, and only in rare cases it is used in practice.

Keywords: occupational therapy, neuropathy, upper extremity, occupational therapy intervention. 
Постановка проблеми. Аналіз останніх досліджень і публікацій. Останнім часом лікування будь-якої патології розглядається 3 точки зору реабілітаційного процесу, який спрямований не тільки на відновлення функціонального стану пацієнта, а й на повернення його в повсякденне життя, суспільство та до професійної діяльності. Для досягнення цієї мети крім лікувальних, фрізіотерапевтичних методів та психокорекції в реабілітаційний процес необхідно включати ерготерапію [5]. До таких захворювань з великою потребою в ерготерапевтичних заходах у відновному лікуванні належать периферичні невропатії верхніх кінцівок.

Захворювання і травми периферичної нервової системи $\epsilon$ соціально значущою проблемою. Пошкодження рук $\epsilon$ найбільш поширеними травмами, отриманими особами переважно працездатного віку. Травматичні та компресійно-ішемічні невропатії верхніх кінцівок становлять 1/3 від усіх захворювань перифреричної нервової системи $[3,7]$.

Компресійно-ішемічні (тунельні) невропатії $\epsilon$ ураженням периферичної нервової системи, що зустрічається досить часто. Вони становлять від 25 до $42 \%$ від усіх захворювань перисреричних нервів [12]. У літературі описано понад 30 форм тунельних невропатій. Стінки анатомічного тунелю - це природні анатомічні структури (кістки, сухожилки, м'язи). У нормі через тунель проходять судини та нерви, однак за наявності певних фракторів, а також під впливом зовнішніх чинників відбувається порушення взаємовідношення складових тунеля один відносно іншого $[1,13]$.

Розвиток тунельних синдромів спричиняють однотипні або стереотипні рухи, травми або мікротравми. Тому поширеність тунельних невропатій вірогідно більша в осіб, які займаються певним видом роботи (стенографрістів, секретарів, музикантів, водіїв, садівників, верстальників, осіб, які працюють із відбійним молотком). Інколи компресійно-ішемічні невропатії виникають при використанні милиць, тростини та ін. Сьогодні тунельна невропатія часто зустрічається у всіх тих, хто постійно працює за комп'ютером [2].

Ушкодження периферичних нервів супроводжується порушенням цілісності нервових стовбурів внаслідок впливу механічної дії на них при травмі, пораненні, що спричиняє порушення рухів та чутливості, викликає дегенеративно-дистрофрічні зміни нижче рівня травми. У структурі травм опорно-рухового апарату ушкодження перифреричних нервів становить до $6 \%$, з них $90 \%$ - верхньої кінцівки [4].
За даними І. Б. Третяка, Ю. П. Зозулі зі співавт. [11] щороку у відділенні відновлювальної нейрохірургії проходять лікування близько 300 хворих з ушкодженнями нервів і ця цифрра 3 року в рік зростає. Ушкодження периферичних нервів веде до стійкої інвалідизації пацієнтів.

Клінічна картина залежить від рівня ураження нерва. При невропатії верхніх кінцівок найбільш поширеними симптомами є: слабкість м'язів рук, рухові порушення; порушення координації рухів; зміни в чутливості рук: зниження температурної чутливості, парестезії та атрофрія м'язів верхніх кінцівок, набряклість кінцівок, біль тощо [11].

Актуальність застосування ерготерапії як напряму реабілітації та адаптації до повсякденного життя пацієнтів при невропатіях верхніх кінцівок обумовлена наслідками, викликаними цим захворюванням: втрата працездатності та навичок самообслуговування.

В Україні ще дуже рідко застосовують ерготерапевтичні заходи у пацієнтів з даною патологією, що значно знижує ефективність лікування та реабілітації неврологічних хворих та зумовлює необхідність детального вивчення вказаного реабілітаційного втручання.

Мета дослідження - розкрити значення ерготерапії в реабілітації осіб з невропатіями верхніх кінцівок.

Матеріали і методи дослідження: аналіз та узагальнення науково-методичної літератури та Інтернет джерел.

Результати дослідження. Процес реабілітації передбачає взаємодію ерготерапевта 3 іншими фрахівцями реабілітаційного процесу: неврологом, нейрохірургом, фрізичним терапевтом, медсестрою та іншими фрахівцями. Розробляючи план ерготерапевтичного втручання для даної категорії хворих, необхідно враховувати багато фокторів: який саме нерв верхньої кінцівки уражений, ступінь компресії чи травматизації, метод лікування (консервативний чи оперативний), період перебігу хвороби, етап реабілітації, цілі втручання, потреби та особливості професійної діяльності пацієнта [9].

Процес ерготерапії складається 3 таких етапів: включення клієнта в програму ерготерапії, оцінка, постановка цілей, вибор методів і проведення програми терапії та оцінки змін, які відбулися з пацієнтом за час втручання. Ерготерапевти орієнтуються на індивідуальні проблеми пацієнта і використовують проблемно-орієнтовані методи втручання [8].

Відомо, що під час травми чи компресії нервів руки завжди порушуються рухова фрункція кінцівки, активність та участь. Так, при ураженні 
серединного нерва страждає пронація, послаблюється долонне згинання кисті (зберігається лише за рахунок ліктьового згинача кисті від ліктьового нерва), порушується згинання I, II та III пальців і розгинання середніх фраланг II і III пальців. Атрофрії м'язів при ураженні серединного нерва виражені найбільш чітко в області тенара. Внаслідок цього долоня стає пласкою, великий палець знаходиться впритул до вказівного - все це створює своєрідне положення кисті, яку називають «мавпячою» $[11,13]$.

При ураженні променевого нерва виникає типова «падаюча», або звисаюча, кисть. Серед рухових розладів, які виникають при ураженні променевого нерва, можна зазначити: неможливість розгинання кисті і пальців, відведення великого пальця. Під час розведення складених разом долонями кистей з випрямленими пальцями, пальці ураженої кисті не відводяться.

Рухові розлади, які виникають при ураженні ліктьового нерва: під час стиснення ураженої руки в кулак IV i V, частково III пальці згинаються недостатньо, неможливість згинання кінцевої фраланги V пальця та приведення пальців, особливо IV i V [11, 13].

У процесі ерготерапії дуже важливим етапом $€$ постановка цілей втручання. Вони повинні бути реалістичними, досяжними і такими, щоб була можливість оцінювати зміни, які відбулися у пацієнта в процесі втручання. Спільно $з$ клієнтом формуються довгострокові, більш загальні цілі, які переважно формулюються за результатами оцінки обмежень участі в житті суспільства. Довгострокові цілі створюються 3 розрахунку досягнення через 3-4 міс. До довгострокових можна віднести адаптацію пацієнта до нормального життя, допомогу в досягненні максимальної самостійності і незалежності в побуті та відновлення втрачених рухових функцій верхньої кінцівки [10].

Короткострокові цілі дуже конкретні, орієнтовані на їх досягнення протягом 2-4 тижнів.

На етапі планування втручання важливим етапом $\epsilon$ вибір методів втручання. Внаслідок того що на вибір методів впливає не медичний діагноз, а наявні обмеження життєдіяльності, то найчастіше ерготерапевти використовують комбінацію декількох методів. В ерготерапії існує велика кількість моделей для втручання, які застосовуються у пацієнтів з різними проблемами і для різних цілей [10].

У вітчизняній та зарубіжній літературі підкреслюється, що стратегія втручання в ерготерапії базується на індивідуальному підході до кожного пацієнта. Індивідуальні ерготерапевтичні програми сприяють максимальному використанню функції для задоволення потреб людини в робочому та соціальному середовищі, особистісних та домашніх умовах. Процес ерготерапії базується на первинному та повторному оцінюванні. Ерготерапевт разом із пацієнтом зосереджує увагу на індивідуальних здібностях та особливостях навколишнього середовища, а також на проблемах, пов'язаних із діяльністю особи в повсякденному житті [6, 15].

В ході проведення ерготерапевтичних заходів необхідно дотримуватися таких принципів:

- уявлення про індивідуальну повсякденну діяльність пацієнта повинно складатися на підставі ретельної оцінки фракторів, що включають в себе індивідуальні особливості пацієнта, його соціальну активність і оточуюче середовище. Необхідно скласти уявлення про можливий потенціал хворого з невропатією верхньої кінцівки до розвитку і вдосконалення.

- пацієнт активно втягується в процес ерготерапії. Взаємини між пацієнтом і ерготерапевтом мають характер співробітництва. Вони змінюються залежно від умов існування пацієнта в його соціальному оточенні, а не в лікувальному закладі, і пов'язані з повсякденною діяльністю.

- повсякденна діяльність використовується як терапія. Ерготерапевтичні заняття дозволяють розвивати здібності та навички пацієнтів, які можуть бути використані в повсякденному житті. Вони допомагають пацієнтам адаптуватися до оточуючого середовища [6].

Одним із напрямів ерготерапії у провідних країнах Європи та Північної Америки є терапія рук (Hand Occupational Therapy), яка застосовується при різних захворюваннях і травмах, коли порушується нормальна фрункція руки. В нашій країні тільки розпочато вивчення основних положень даного напряму. В терапії рук використовують підхід, орієнтований на пацієнта/ клієнта, який визначає потреби у повсякденному житті, під час відпочинку та профресійної діяльності. Включення «звичайних і звичних» (usual and customary) ерготерапевтичних активностей в комплекс лікувальних заходів та орієнтація цілей на забезпечення їх виконання підвищує еорективність реабілітації у даної категорії хворих [17].

У пацієнтів з невропатіями верхньої кінцівки застосовують основні стратегії відновлення можливостей хворого - розвиваючу та компенсаторну. Розвиваюча стратегія - відновлення втраченої функції. Це проведення заходів щодо можливого відновлення фрункції верхньої кінцівки: плеча, передпліччя i, особливо, кисті [10]. 
Компенсаторна стратегія - заміщення втраченої функції. Якщо відновити втрачену функцію кисті неможливо - необхідно підібрати ортези, що дозволяють полегшити виконання втраченої функції: спеціальні за конструкцією вилки, ложки, кружки, дверні ручки, пристосування для одягання у вигляді гачків на довгих ручках та ін. Компенсаторна стратегія використовується тільки в тих випадках, коли відновлення втраченої фрункції неможливо навіть частково [10].

Ряд дослідників вважають, що ерготерапевтичне втручання може починатися з підготовчих методів (наприклад, зміцнення м'язів, збільшення діапазону рухів в ураженій кінцівці) або цілеспрямованих дій (наприклад, модельованих занять, компонентів занять або інших значущих дій відповідно до потреб та профресії клієнта). У міру поліпшення стану ураженої верхньої кінцівки втручання розширюється, щоб охопити виконання бажаних повсякденних дій та завдань профресії (наприклад, самообслуговування, приготування їжі, робочі дії та ін.). Терапевт ретельно вибирає активності, щоб бути впевненими, що вони пов'язані з компонентами або фрактичними діями, які пацієнт буде виконувати під час або після реабілітації, і пов'язує методи ерготерапії з кінцевою лікувальною метою - максимально можливо відновити активну участь

\section{Література}

1. Бісмак ОВ. Периферичні невропатії верхньої кінцівки як медико-соціальна проблема [Peripheral neuropathies of the upper limb as a medical and social problem]. Науковий часопис Національного педагогічного університету імені М.П. Драгоманова. Серія № 15. Науково-педагогічні проблеми фрізичної культури (фізична культура і спорт). 2019;7(115)19: 12-16.

2. Богов АА, Васильев МВ, Филимонычев ДА. Туннельные поражения нервных стволов верхней конечности [Tunne lesions of the nerve trunks of the upper limb]. Казанский медицинский журнал. 2009; 90(4):593-597.

3. Вишневський ВО. Причини, діагностичні помилки при ушкодженнях периферичних нервів кінцівок [Causes, diagnostic errors in injuries of peripheral nerves of limbs]. Запорізький медичний журнал. 2014;4(85):50-55.

4. Котов АС, Елисеев ЮВ. Туннельные синдромы [Tunnel syndromes]. Русский медицинский журнал. 2014;22:1586-87.

5. Мальцева МН, Шмонин АA, Мельникова ЕВ, Иванова ГЕ. Эрготерапия в реабилитации неврологических пациентов [Occupational therapy in the rehabilitation of neurological patients]. Consilium Medicum. 2016;13:59-60.

6. Мошовська II, Рокошевська ВВ. Особливості програми ерготерапії для осіб з когнітивними порушеннями внаслідок перенесеної черепно-мозкової травми [Features of an occupational therapy program for persons with cognitive impairment due to a traumatic brain injury]. PMJUA [Internet] 2018, Oct.18 [cited 20190ct.30];3(2/1):54. Available from: https://painmedicine.org.ua/index.php/pnmdcn/article/view/146. пацієнта в повсякденній та професійній діяльності $[16,18]$.

В літературі відзначається, що велике значення має визначення ефективності ерготерапевтичних заходів у пацієнтів з невропатіями верхньої кінцівки. Для оцінки ефективності заходів використовуються шкали оцінки рівня фрункціонування: вимірюють можливість повного тілесного самообслуговування і користування предметами побуту; вимірюють локально ті функції, розлад яких призводить до порушення життєдіяльності; поєднують вимір повсякденної активності та рольових обмежень [14].

Висновки. Ерготерапія $\epsilon$ важливою складовою реабілітаційного процесу в осіб з травматичними та компресійно-ішемічними невропатіями верхніх кінцівок, яка направлена на підвищення якості життя пацієнтів та відновлення або покращення активності та участі пацієнтів в усіх сферах людського життя. Проте літературні дані свідчать, що в нашій країні ще недостатньо уваги приділяють використанню ерготерапії при пошкодженнях периферичних нервів верхньої кінцівки і лише в поодиноких випадках застосовують на практиці.

Перспективи подальших досліджень. У перспективі планується розробка алгоритму застосування засобів ерготерапії при невропатіях верхньої кінцівки та вивчення його ефективності.

7. Репина ВВ, Данилов АБ, Воробьева ЮД. Туннельные синдромы как причина боли в области шеи и руке [Tunnel syndromes as a cause of pain in the neck and arm]. Русский медицинский журнал. 2015;1:33-4.

8. Супонева НА, Мальцева МН, Зимин АА. Методические основы применения эрготерапии в реабилитации больных с острым нарушением мозгового кровообращения [Methodological principles of the use of occupational therapy in the rehabilitation of patients with acute cerebrovascular accident]. Вестник восстановительной медицины. 2017, 2:68-73.

9. Такенов ЖТ, Борисюк НВ. Эрготерапия в реабилитации пациентов с двигательными расстройствами [Ergotherapy for rehabilitation of patients with motor disorders]. Нейрохирургия и неврология Казахстана. 2017;1(46):27-30.

10. Таран IB, Валюшко Ю. Ерготерапія, як сучасний напрямок фрізичної реабілітації хворих із травмами й захворюваннями нервової системи [Осcupational therapy as a modern direction of physical rehabilitation of patients with injuries and diseases of the nervous system]. Теоретичні та методичні проблеми фрізичної реабілітації. Матеріали VI Всеукр. наук.метод. конф. Херсон. 2016; 292-8.

11. Третяк ІБ, Зозуля ЮП, Цимбалюк ЮВ, Сапон МА. Відновне хірургічне лікування наслідків ушкодження довгих гілок плечового сплетення з використанням тривалої електростимуляції [Reconstructive surgical treatment of the effects of damage to the long branches of the brachial plexus using prolonged electrical stimulation]. Украинский нейрохирургический журнал. 2013;2:19-22. 
12. Цимбалюк ВІ, Цимбалюк ЮВ. Тунельні невропатії верхньої кінцівки [Tunnel neuropathies of the upper limb]. Київ, 2008; 200 c.

13. Цимбалюк ЮВ. Відновне нейрохірургічне лікування ушкоджень перифреричних нервів із застосуванням довготривалої електростимуляиії [Reconstructive neurosurgical treatment of peripheral nerve injuries using prolonged electrical stimulation] [авторесрерат]. Київ; 2014. 40 с.

14. Amini D. Occupational Therapy Interventions for WorkRelated Injuries and Conditions of the Forearm, Wrist, and Hand: A Systematic Review. American Journal of Occupational Therapy, January/February. 2011;65:29-36.

15. Cole T, Robinson L, Romero L, O'Brien L. Effectiveness of interventions to improve therapy adherence in people with ebismak@gmail.com upper limb conditions: A systematic review. Journal of Hand Therapy. 2017;32(2):175-183.

16. Custer MG, Huebner RA, Howell DM. Factors predicting client satisfaction in occupational therapy and rehabilitation. American Journal of Occupational Therapy. 2014;69: 1-10.

17. Takata SC, Wade ET, Roll SC. Hand therapy interventions, outcomes, and diagnoses evaluated over the last 10 years: A mapping review linking research to practice. Journal of Hand Therapy. 2017; 32(1):1-9.

18. Townsend E, Polatajko H. Enabling occupation II: Advancing an occupational therapy vision for health, well-being, justice through occupation. Canadian Association of Occupational Therapists, 2013. $428 \mathrm{p}$.

Надійшла 28.10.2019 